OPEN ACCESS

Edited by: Hyun Kook Lim,

The Catholic University of Korea,

South Korea

Reviewed by:

Hernando Santamaría-García,

Pontifical Javeriana University,

Colombia

Veronica Perez De La Cruz,

National Institute of Neurology and

Neurosurgery (INNN), Mexico

${ }^{*}$ Correspondence:

Hong Jin Jeon

jeonhj@skku.edu

Specialty section: This article was submitted to Aging Psychiatry, a section of the journal

Frontiers in Psychiatry

Received: 02 March 2019 Accepted: 27 June 2019

Published: 19 July 2019

Citation:

Park MJ, Kim DJ, Lee U, Na EJ and Jeon HJ (2019) A Literature Overview

of Virtual Reality (VR) in Treatment

of Psychiatric Disorders: Recent

Advances and Limitations.

Front. Psychiatry 10:505.

doi: 10.3389/fpsyt.2019.00505

\section{A Literature Overview of Virtual Reality (VR) in Treatment of Psychiatric Disorders: Recent Advances and Limitations}

\author{
Mi Jin Park ${ }^{1}$, Dong Jun Kim², Unjoo Lee ${ }^{3}$, Eun Jin $\mathrm{Na}^{1}$ and Hong Jin Jeon ${ }^{1,2 *}$ \\ ${ }^{1}$ Department of Psychiatry, Depression Center, Samsung Medical Center, Sungkyunkwan University School of Medicine, \\ Seoul, South Korea, ${ }^{2}$ Department of Health Sciences \& Technology, Department of Medical Device Management \& \\ Research, and Department of Clinical Research Design \& Evaluation, Samsung Advanced Institute for Health Sciences \\ \& Technology (SAIHST), Sungkyunkwan University, Seoul, South Korea, ${ }^{3}$ Department of Electronic Engineering, Hallym \\ University, Kangwon, South Korea
}

In this paper, we conduct a literature survey on various virtual reality (VR) treatments in psychiatry. We collected 36 studies that used VR to provide clinical trials or therapies for patients with psychiatric disorders. In order to gain a better understanding of the management of pain and stress, we first investigate VR applications for patients to alleviate pain and stress during immersive activities in a virtual environment. VR exposure therapies are particularly effective for anxiety, provoking realistic reactions to feared stimuli. On top of that, exposure therapies with simulated images are beneficial for patients with psychiatric disorders such as phobia and posttraumatic stress disorder (PTSD). Moreover, VR environments have shown the possibility of changing depression, cognition, even social functions. We review empirical evidence from VR-based treatments on psychiatric illnesses such as dementia, mild cognitive impairment $(\mathrm{MCl})$, schizophrenia and autism. Through cognitive training and social skill training, rehabilitation through VR therapies helps patients to improve their quality of life. Recent advances in VR technology also demonstrate potential abilities to address cognitive and functional impairments in dementia. In terms of the different types of VR systems, we discuss the feasibility of the technology within different stages of dementia as well as the methodological limitations. Although there is room for improvement, its widespread adoption in psychiatry is yet to occur due to technical drawbacks such as motion sickness and dry eyes, as well as user issues such as preoccupation and addiction. However, it is worth mentioning that VR systems relatively easily deliver virtual environments with well-controlled sensory stimuli. In the future, VR systems may become an innovative clinical tool for patients with specific psychiatric symptoms.

Keywords: virtual reality, psychiatric treatment, psychiatric disorders, dementia, motion sickness 


\section{INTRODUCTION}

Virtual reality (VR) is defined as a computer-generated simulation, such as a set of images and sounds that represents a real place or situation, that can be interacted with, in a seemingly real or physical way by a person using special electronic equipment. It can transmit visual, auditory, and various sensations to users through a headset to make them feel as if they are in a virtual or imagined environment (1).

The concept of VR was introduced in the 1950s, and the maturity of VR for entertainment is now evident. Currently, more than 230 companies are producing various products related to VR and performing research and development, including global companies such as Samsung Electronics, Apple, Facebook, Amazon, and Microsoft. VR systems consist of VR headsets, a computer, and video. Recently, chairs, gloves, and sensors have been added. VR headsets refer to head-mounted goggles. They are equipped with a speaker or headphones. VR systems that include the transmission of vibrations and other sensations to the user through a game controller, gloves or chairs are known as haptic feedback systems (2). This tactility is advantageous as the sense of presence can be improved by actually sensing the shock or vibration to the user in the medical field, video games, and military training. A 4D (four-dimensional) system of VR refers to a VR system with a motion chair that enhances reality for users with integrated movement according to the content of the VR video. Depending on the type of system and programing, the user may interact with the environment from a first- or third-person's point of view. In the case of the latter, the user can move around a virtual representation of themselves, called an 'avatar' (3).

In medical fields, multidisciplinary research has tried to apply VR systems to domains of diagnosis, treatment, and so on. Especially, in psychiatry, traditional tools of treatment have mainly been limited to interpersonal psychotherapy and medication. However, VR can provide various types of stimulation (4). Intuitively, it helps in relieving pain, stress, and anxiety in an imagined space, and VR makes it possible to provide efficient educational and psychological training without causing harm to patients (5). It therefore has the possibility of changing PTSD, phobia, anxiety, depression, cognition, and social functions in patients with psychiatric illnesses.

Indeed, over the past few decades, therapeutic virtual reality (VR) has emerged as a successful solution for a wide range of psychiatric disorders. In the 1990s, Rothbaum et al. conducted the first study in the field of psychiatry to investigate the efficacy of VR focusing one treating acrophobia in college students and found that VR is successful in reducing their fear of heights (6). The early studies established the efficacy of VR exposure therapy for a number of anxiety and related disorders. For example, VR exposure therapies have shown benefits for patients with a specific phobia or posttraumatic stress disorder (PTSD) by the extinction of traumatic experiences through their repetitive exposures, and the extinction of pain by pulling the patients focus away from painful conditions. The broad reach of VR has enabled its use in the evaluation and rehabilitation of patients with schizophrenia and autism through improvements of their social activities. The reports included in this review, show that VR is also an efficacious way for Amnestic MCI (mild cognitive impairment) and early to moderate Alzheimer's disease through cognitive reserve and training.

VR-based treatment currently faces hurdles preventing its wide use as a real tool in psychiatry practice, such as motion sickness and dry eyes as well as user issues such as preoccupation and addiction. However, VR systems can deliver and confront virtual environments with well-controlled sensory stimuli. With a review of the current utilization of VR in the field of psychiatry, we highlight both the benefits and limitations of VR use, as it is just beginning to be applied as a new modality in psychiatry. We have tried to describe the evidence of the utility of VR in psychiatric conditions and the types of procedures followed in those studies

\section{METHODS AND RESULTS}

To identify 'virtual reality' in the field of psychiatry, a PubMed literature search was performed which included articles published prior to 31 December 2018, and which included the terms "virtual reality" and "psychiatry" and "treatment" or "therapy." We then categorized them as articles related to "posttraumatic Stress Disorders (PTSD)," " phobia," "anxiety disorders," "schizophrenia," "autism," "dementia and mild cognitive impairment (MCI)," and "pain and stress." Additional relevant articles were found through a manual bibliographic search. Eligibility criteria were: 1) articles in English; 2) human studies; and 3) articles focused on virtual reality and psychiatric disorders. We collect 36 studies that made use of VR to provide various types of stimulations for patients with psychiatric problems (Table 1).

\section{DISCUSSION}

\section{Treatment of Posttraumatic Stress Disorders (PTSD)}

Posttraumatic Stress Disorder (PTSD) is a psychological reaction that occurs after experiencing stress that has caused lifethreatening extreme mental trauma (42). An individual's quality of life is greatly reduced by re-experiencing the situation with awakening, anxiety, agitation, and insomnia symptoms. Among PTSD, many VR studies have been focused on veterans who have been exposed to battles in Iraq and Afghanistan, to alleviate their trauma (43), reduce suicidal ideation (44), decrease depression and anger (16), and to improve their PTSD (30). Discharged soldiers can have destructive behaviors to both themselves and others as a result of rage and depression caused by PTSD. However, they can learn to solve these situations in a safe and wellcontrolled environment called VR. Since the key in the emotionprocessing theory (EPT) is to expose and modify their unique fear structure, the virtual environment is ideal in the sense of its flexibility and customization (45). As they are exposed to sources of their disorder, they decrease the feelings of fear and anxiety in the form of VR-based habituation therapy. Dr. Rothbaum at the Emory University Hospital provided a randomized, double-blind, 
TABLE 1 | Clinical trials or therapies with virtual reality (VR) in psychiatry.

\begin{tabular}{|c|c|c|c|c|}
\hline $\begin{array}{l}\text { Author and date of } \\
\text { publication }\end{array}$ & Subjects & Design & Method & Conclusions \\
\hline Doniger et al., 2018 (7) & $\begin{array}{l}\text { Middle-aged adults with } \\
\text { Alzheimer's disease family } \\
\text { history }(n=125)\end{array}$ & $\mathrm{RCT}$ & $\begin{array}{l}\text { VR cognitive-motor training, } 45 \text { min, } \\
\text { twice/week for } 12 \text { weeks }\end{array}$ & Increased cognitive function \\
\hline Reger et al., 2019 (8) & $\begin{array}{l}\text { Active duty soldiers with PTSD } \\
(n=108)\end{array}$ & Observational & $\begin{array}{l}\text { Randomization to exposure via } 10 \\
\text { sessions of prolonged exposure or } \\
\text { VRE or 5-week minimal attention } \\
\text { waitlist }\end{array}$ & $\begin{array}{l}\text { No group differences in average or peak } \\
\text { subjective distress during exposure therapy }\end{array}$ \\
\hline $\begin{array}{l}\text { Flores et al., } \\
2018(9)\end{array}$ & $\begin{array}{l}\text { Two patients with spinal cord } \\
\text { injury with psychiatric symptoms }\end{array}$ & Case report & $\begin{array}{l}4 \text { VR DBT sessions for Patient 1, } 2 \\
\text { VR DBT sessions for Patient } 2\end{array}$ & $\begin{array}{l}\text { Reductions in negative emotions for Patient } \\
1 \text {, mixed results for Patient } 2\end{array}$ \\
\hline $\begin{array}{l}\text { Peskin et al., } \\
2018(10)\end{array}$ & $\begin{array}{l}\text { Men and women with World } \\
\text { trade center-related PTSD } \\
(n=25)\end{array}$ & $\mathrm{RCT}$ & $\begin{array}{l}100 \text { mg D-cycloserine versus } \\
\text { placebo augmented VRE sessions for } \\
12 \text { weeks }\end{array}$ & $\begin{array}{l}\text { Temporal relationship between } \\
\text { posttraumatic and depressive symptoms. } \\
\text { during VRE }\end{array}$ \\
\hline $\begin{array}{l}\text { Du Sert et al., } \\
2018(11)\end{array}$ & $\begin{array}{l}\text { Schizophrenia patients with } \\
\text { refractory } \mathrm{AVH} \\
(n=19)\end{array}$ & $\mathrm{RCT}$ & $\begin{array}{l}\text { A 7-week phase-II, randomized, } \\
\text { partial cross-over trial }\end{array}$ & $\begin{array}{l}\text { Significant improvements in severity of } \\
\text { auditory visual hallucination, depressive } \\
\text { symptoms and quality of life }\end{array}$ \\
\hline $\begin{array}{l}\text { Pot-Kolder et.al., } 2018 \\
\text { (12) }\end{array}$ & $\begin{array}{l}\text { Patients with a psychotic } \\
\text { disorder and paranoid ideation } \\
(n=116)\end{array}$ & $\mathrm{RCT}$ & $\begin{array}{l}\text { VR-CBT with treatment as usual, } \\
1 \mathrm{~h} \text { long, } 16 \text { individual session versus } \\
\text { treatment as usual }\end{array}$ & $\begin{array}{l}\text { Significant reduction in momentary } \\
\text { paranoid ideation and anxiety }\end{array}$ \\
\hline Gold et al., 2018 (13) & $\begin{array}{l}\text { Child and adolescent patients } \\
(n=143)\end{array}$ & $\mathrm{RCT}$ & $\begin{array}{l}\text { Totally } 5 \text { min long VR game with } \\
\text { standard of care versus standard of } \\
\text { care only }\end{array}$ & $\begin{array}{l}\text { Significant reduction in acute procedural } \\
\text { pain and anxiety }\end{array}$ \\
\hline Gomez et al., 2017(14) & $\begin{array}{l}21 \text {-year-old Latino male patient } \\
\text { with burn injury }\end{array}$ & Observational & $\begin{array}{l}\text { Immersive VR enhanced DBT } \\
\text { mindfulness skills training, } 4 \text { sessions } \\
\text { for } 1 \text { month }\end{array}$ & $\begin{array}{l}\text { Increased positive emotions and decreased } \\
\text { negative emotions }\end{array}$ \\
\hline Ryu et al., 2017 (15) & $\begin{array}{l}\text { Children scheduled for elective } \\
\text { surgery } \\
(n=69)\end{array}$ & $\mathrm{RCT}$ & $\begin{array}{l}\text { Preoperative VR tour of the operating } \\
\text { theatre, } 4 \text { min video }\end{array}$ & $\begin{array}{l}\text { Lower scores of the Yale Preoperative } \\
\text { Anxiety Scale, Induction Compliance } \\
\text { Checklist, and Procedural Behavior Rating } \\
\text { Scale }\end{array}$ \\
\hline $\begin{array}{l}\text { Eijlers et al. } \\
2017(16)\end{array}$ & $\begin{array}{l}\text { Children undergoing elective day } \\
\text { care surgery } \\
(n=200)\end{array}$ & $\mathrm{RCT}$ & Preoperative VRE intervention, 15 min & $\begin{array}{l}\text { Diminished preoperative anxiety, } \\
\text { postoperative pain, and the use of } \\
\text { postoperative analgesics }\end{array}$ \\
\hline $\begin{array}{l}\text { Beidel et al., } \\
2017 \text { (17) }\end{array}$ & $\begin{array}{l}\text { Veterans and active duty soldiers } \\
\text { with combat-related PTSD } \\
(n=92)\end{array}$ & $\mathrm{RCT}$ & $\begin{array}{l}\text { VRET plus group treatment versus } \\
\text { VRET with psychoeducation control }\end{array}$ & $\begin{array}{l}\text { Decrease on PTSD scale for both group } \\
\text { and decrease in social isolation for VRET } \\
\text { plus group treatment }\end{array}$ \\
\hline $\begin{array}{l}\text { Ferrer-Garcia et al., } \\
2017 \text { (18) }\end{array}$ & $\begin{array}{l}\text { Patients with bulimia nervosa } \\
\text { and binge eating disorder } \\
(n=64)\end{array}$ & Case control & $\begin{array}{l}\text { Two second-level treatment } \\
\text { condition: VR- Cue Exposure Therapy } \\
\text { or additional CBT }\end{array}$ & $\begin{array}{l}\text { More proportion of achievement } \\
\text { abstinence from binge eating or purging } \\
\text { episodes }\end{array}$ \\
\hline $\begin{array}{l}\text { Blume et al., } \\
2017 \text { (19) }\end{array}$ & Children with ADHD $(n=90)$ & $\mathrm{RCT}$ & $\begin{array}{l}15 \text { training sessions of either NIRS } \\
\text { based NFT in VR, NIRS based NFT } \\
\text { in 2D or biofeedback training in VR, } \\
60-70 \text { min for each session }\end{array}$ & $\begin{array}{l}\text { NFT in VR is expected to yield greater } \\
\text { effects than training in } 2 \mathrm{D}\end{array}$ \\
\hline $\begin{array}{l}\text { Shiban et al., } \\
2017(20)\end{array}$ & 29 patients with aviophobia & $\mathrm{RCT}$ & $\begin{array}{l}\text { VRE treatment either with or without } \\
\text { diaphragmatic breathing }\end{array}$ & $\begin{array}{l}\text { Higher tendency to effectively overcome } \\
\text { the fear of flying in VR with diaphragmatic } \\
\text { breathing }\end{array}$ \\
\hline $\begin{array}{l}\text { Bouchard et al., } \\
2017 \text { (21) }\end{array}$ & $\begin{array}{l}\text { Patients with social anxiety } \\
\text { disorder }(N=59)\end{array}$ & RCT & $\begin{array}{l}14 \text { weekly sessions for VR exposure } \\
\text { or in vivo exposure or waiting list }\end{array}$ & $\begin{array}{l}\text { Improvement in both CBT groups, more } \\
\text { effective in VRE }\end{array}$ \\
\hline $\begin{array}{l}\text { Reger et al., } \\
2016 \text { (22) }\end{array}$ & $\begin{array}{l}\text { Active-duty soldiers } \\
(n=162)\end{array}$ & $\mathrm{RCT}$ & $\begin{array}{l}\text { Randomization to } 10 \text { sessions of } \\
\text { Prolonged exposure, VRE, or a } \\
\text { minimal attention waitlist }\end{array}$ & $\begin{array}{l}\text { Significant reductions in PTSD symptoms } \\
\text { in Prolonged exposure and VRE groups }\end{array}$ \\
\hline $\begin{array}{l}\text { Norrholm et al., } \\
2016(23)\end{array}$ & $\begin{array}{l}\text { Participants met criteria for } \\
\text { PTSD }(n=50)\end{array}$ & $\mathrm{RCT}$ & $\begin{array}{l}6 \text { weeks of VRE therapy combined } \\
\text { with d-cycloserine, alprazolam, or } \\
\text { placebo }\end{array}$ & $\begin{array}{l}\text { In the d-cycloserine group, elevated } \\
\text { startle before VR therapy predicted better } \\
\text { outcome }\end{array}$ \\
\hline $\begin{array}{l}\text { Son et al., } \\
2015(24)\end{array}$ & $\begin{array}{l}\text { Alcohol dependent subjects } \\
(n=12)\end{array}$ & $\begin{array}{l}\text { Case control } \\
\text { study }\end{array}$ & $\begin{array}{l}10 \text { sessions of } V R E T \text {, consisted of } \\
3 \text { steps: relaxation, presentation of } \\
\text { a high risk situation, and aversive } \\
\text { situation }\end{array}$ & $\begin{array}{l}\text { Decreased metabolism in the basal ganglia } \\
\text { after VRET (PET shows) }\end{array}$ \\
\hline $\begin{array}{l}\text { Jahani Shoorab et.al., } \\
2015 \text { (25) }\end{array}$ & $\begin{array}{l}\text { Primiparous parturient women } \\
\text { having labor } \\
(n=30)\end{array}$ & $\mathrm{RCT}$ & $\begin{array}{l}\text { Randomization to VR with standard } \\
\text { care group and only standard care } \\
\text { group }\end{array}$ & $\begin{array}{l}\text { Decreased pain during the episiotomy } \\
\text { repair } \\
\text { When use of VR with local anesthesia }\end{array}$ \\
\hline
\end{tabular}


TABLE 1 | Continued

\begin{tabular}{|c|c|c|c|c|}
\hline $\begin{array}{l}\text { Author and date of } \\
\text { publication }\end{array}$ & Subjects & Design & Method & Conclusions \\
\hline $\begin{array}{l}\text { Rothbaum et al., } 2014 \\
\text { (26) }\end{array}$ & $\begin{array}{l}\text { Iraq and Afghanistan war } \\
\text { veterans with PTSD }(n=156)\end{array}$ & $\mathrm{RCT}$ & $\begin{array}{l}\text { An introductory session and five } \\
\text { sessions of VRE augmented with } \\
\text { d-cycloserine or alprazolam or } \\
\text { placebo }\end{array}$ & $\begin{array}{l}\text { Significantly improved PTSD symptoms } \\
\text { from pre- to posttreatment across all } \\
\text { conditions }\end{array}$ \\
\hline Marco et al., 2013 (27) & $\begin{array}{l}\text { Participants diagnosed with } \\
\text { eating disorders } \\
(n=34)\end{array}$ & $\begin{array}{l}\text { Case control } \\
\text { study }\end{array}$ & $\begin{array}{l}15 \text { CBT group sessions and } 8 \\
\text { individual psychotherapy sessions } \\
\text { with VR }\end{array}$ & $\begin{array}{l}\text { Improved body image and this } \\
\text { improvement was maintained at the one- } \\
\text { year follow-up }\end{array}$ \\
\hline $\begin{array}{l}\text { Pallavicini et al., } 2013 \\
\text { (28) }\end{array}$ & Undergraduate students $(n=39)$ & $\begin{array}{l}\text { Case control } \\
\text { study }\end{array}$ & $\begin{array}{l}\text { Same experience was offered using } \\
\text { test, audio, video, and VR }\end{array}$ & $\begin{array}{l}\text { VR was less effective than other } \\
\text { procedures in eliciting stressor responses }\end{array}$ \\
\hline Diemer et al., 2013 (29) & $\begin{array}{l}\text { Patients with arachnophobia } \\
(n=58)\end{array}$ & $\mathrm{RCT}$ & $\begin{array}{l}\text { A single dose of quetiapine XR or } \\
\text { placebo prior to a VR }\end{array}$ & $\begin{array}{l}\text { Effect of VR challenge on behavioral } \\
\text { avoidance, psychophysiological reaction }\end{array}$ \\
\hline Malbos et al., 2013 (30) & $\begin{array}{l}\text { Agoraphobic participants }(n \\
=18)\end{array}$ & $\begin{array}{l}\text { Case control } \\
\text { study }\end{array}$ & $\begin{array}{l}\text { VRET only and VRET with cognitive } \\
\text { therapy }\end{array}$ & $\begin{array}{l}\text { The isolated effects of VRET did not seem } \\
\text { to be less than the effects of VRET with } \\
\text { cognitive therapy }\end{array}$ \\
\hline McLay et al. 2012 (31) & $\begin{array}{l}\text { Active duty service members } \\
\text { with PTSD } \\
(n=20)\end{array}$ & Observational & Open-label, single-group VRET & $\begin{array}{l}\text { Reduction in PTSD symptoms, } \\
\text { improvement in PTSD, depression and } \\
\text { anxiety }\end{array}$ \\
\hline $\begin{array}{l}\text { Culbertson et al., } 2012 \\
\text { (32) }\end{array}$ & $\begin{array}{l}\text { Healthy treatment-seeking } \\
\text { cigarette smokers }(n=11)\end{array}$ & $\mathrm{RCT}$ & $\begin{array}{l}\text { Randomization to CBT plus either } \\
\text { smoking-VR Cue Exposure Therapy } \\
\text { or placebo-VR Cue Exposure } \\
\text { Therapy }\end{array}$ & $\begin{array}{l}\text { Higher quit rate, smoking fewer cigarettes } \\
\text { per day }\end{array}$ \\
\hline Park et al., 2011 (33) & $\begin{array}{l}\text { Inpatients with schizophrenia } \\
(n=91)\end{array}$ & $\mathrm{RCT}$ & $\begin{array}{l}\text { Comparison social skills training using } \\
\text { VR role playing to social skills training } \\
\text { using traditional role playing, over } 10 \\
\text { semiweekly sessions for } 5 \text { weeks }\end{array}$ & $\begin{array}{l}\text { Improved more in conversational skills and } \\
\text { assertiveness }\end{array}$ \\
\hline McLay et al., 2011 (34) & $\begin{array}{l}\text { Active duty military personnel } \\
\text { with combat-related PTSD } \\
(n=10)\end{array}$ & $\mathrm{RCT}$ & $\begin{array}{l}\text { Randomization to VR-graded } \\
\text { exposure therapy or treatment as } \\
\text { usual }\end{array}$ & $\begin{array}{l}\text { Higher number of improvements reported, } \\
\text { more improvement on the CAPS score }\end{array}$ \\
\hline $\begin{array}{l}\text { St-Jacques et al., } 2010 \\
\text { (35) }\end{array}$ & $\begin{array}{l}\text { Agoraphobic participants } \\
(n=31)\end{array}$ & $\mathrm{RCT}$ & $\begin{array}{l}\text { Randomization to in vivo exposure } \\
\text { alone or in virtual reality-based } \\
\text { exposure }\end{array}$ & $\begin{array}{l}\text { VR did not increase motivation toward } \\
\text { psychotherapy }\end{array}$ \\
\hline Gerardi et al., 2008 (36) & A 29-year-old veteran & Case report & $\begin{array}{l}\text { 90-min individual session, once } \\
\text { weekly over } 4 \text { weeks }\end{array}$ & $\begin{array}{l}\text { Decreased rating scale scores (CAPS, } \\
\text { PTSD Symptom Scale Self-Report) }\end{array}$ \\
\hline Difede et al., 2007 (37) & $\begin{array}{l}\text { Male disaster workers with } \\
\text { PTSD }(n=21)\end{array}$ & $\begin{array}{l}\text { Case control } \\
\text { study }\end{array}$ & $\begin{array}{l}\text { Assignment to a VR treatment or a } \\
\text { waitlist control }\end{array}$ & Significant decline in CAPS scores \\
\hline Walshe et al., 2003 (38) & $\begin{array}{l}\text { Subjects with simple phobia/ } \\
\text { accident phobia }(n=14)\end{array}$ & Observational & $\begin{array}{l}\text { An open study, computer games and } \\
\text { virtual reality therapy, } 121 \text {-h sessions }\end{array}$ & $\begin{array}{l}\text { Significant post treatment reductions on all } \\
\text { measures }\end{array}$ \\
\hline $\begin{array}{l}\text { Rothbaum et al., } 2001 \\
\text { (39) }\end{array}$ & $\begin{array}{l}\text { Male Vietnam combat veterans } \\
\text { with PTSD }(n=10)\end{array}$ & Observational & $\begin{array}{l}\text { Open clinical trial, } 8 \text { to } 16 \text { sessions, } 2 \\
\text { virtual environments }\end{array}$ & $\begin{array}{l}\text { Significant reduction from baseline in } \\
\text { symptoms }\end{array}$ \\
\hline $\begin{array}{l}\text { Rothbaum et al., } 2000 \\
\text { (40) }\end{array}$ & $\begin{array}{l}\text { Patients with fear of flying } \\
(n=49)\end{array}$ & $\begin{array}{l}\text { Case control } \\
\text { study }\end{array}$ & $\begin{array}{l}\text { Randomization to VRE therapy, } \\
\text { standard exposure therapy, or a wait- } \\
\text { list control, } 4 \text { sessions of exposure } \\
\text { out of } 8 \text { sessions }\end{array}$ & $\begin{array}{l}\text { VRE and standard exposure both superior } \\
\text { to wait-list }\end{array}$ \\
\hline $\begin{array}{l}\text { Rothbaum et al., } 1999 \\
\text { (41) }\end{array}$ & $\begin{array}{l}\text { A Vietnam combat veteran with } \\
\text { PTSD }\end{array}$ & Observational & VRE, 2 virtual environments & Decrease on CAPS and self-rated PTSD \\
\hline $\begin{array}{l}\text { Rothbaum et al., } 1996 \\
\text { (42) }\end{array}$ & $\begin{array}{l}\text { A } 42 \text {-year-old female with a } \\
\text { debilitating fear and avoidance } \\
\text { of flying }\end{array}$ & Case report & $\begin{array}{l}\text { Anxiety management techniques and } \\
\text { the VRE }\end{array}$ & $\begin{array}{l}\text { All self-report measures of fear and } \\
\text { avoidance of flying decreased }\end{array}$ \\
\hline
\end{tabular}

RCT, randomized controlled trial; VR, virtual reality; VRE, virtual reality exposure; VRET, virtual reality exposure therapy; DBT, dialectical behavior therapy; PTSD, posttraumatic stress disorder; CBT, cognitive-behavioural therapy; NIRS, near-infrared spectroscopy; CAPS, clinician administered PTSD scale; NFT, neurofeedback training.

six-session VR exposure treatment in 156 patients diagnosed with PTSD among discharged soldiers returning from the Iraq and Afghan wars (26). The study concluded that VR treatment was associated with the reduction in PTSD diagnoses and symptoms in Iraq and Afghanistan veterans. Another study suggested that VR with skin conductance reactivity is a diagnostic tool for PTSD as well as a treatment (47). Veterans with PTSD displayed larger skin conductance reactivity across VR combat events, but not for non-combat VR events. The VR exposure therapy system,
"Bravemind," is currently distributed to over 50 sites, including VA hospitals, military bases, and university centers to provide relief from PTSD for soldiers (48).

\section{Anxiety Disorders and Specific Phobia}

These days, some VR systems create highly immersive experiences using more invasive devices such as Head mounted Display (HMDs). A new generation of realistic simulation can therefore 
serve as a promising assessment and therapy for erroneous anxietyprovoking thinking. In general, these symptoms are viewed as serious conditions where patients worry about something fearful excessively and persistently. Reproducing the traditional exposure interventions in VR, Maples-Keller et al. reviewed several case studies of social anxiety disorders and generalized anxiety disorders (49). This is merely the beginning of an explosion in potential provided by ever increasing sophisticated technology. It worth noting that the effectiveness of applying VR in this domain is also quantitatively being analyzed (50).

More specifically, phobia is a type of anxiety disorder characterized by marked and persistent fears that are cued by the presence or anticipation of specific objects or situations with a desire to avoid that condition due to high levels of fear and discomfort (43). Phobia includes acrophobia, flight phobia, phobias for insects or animals, and so on. Exposure therapy in VR is helpful because we can deal with such specific phobias in a virtual world, and it can be cost-effectively performed (29). In VR, patients with phobia can reproduce the situation they actually feel fearful of and face it themselves. Repeated use of VR increases the threshold of anxiety and makes it less insensitive, resulting in the reduced incidence of actual situations. Initially, VR graded exposure therapy was found to be successful in reducing fear of spiders $(51,52)$, social phobia $(53)$, and flight phobia $(3,54)$ after applying it to a small number of subjects. A self-training program with mobile VR individuals with acrophobia has been safely and successfully applied to reduce fear of heights (55). It can be safely applied at home and at the hospital. It can be easily interrupted or repeated depending on the situation. VR can reduce the degree of anxiety by exposing the patient to a virtual dental care scenario in an incremental manner $(56,57)$. Similarly, a pilot study has applied a VR headset as a fear reduction tool and pain distraction for fear of needles, where $94.1 \%$ of pediatric subjects reported an improvement after using VR during immunization (58). Recently, VR with repetitive transcranial magnetic stimulation (rTMS) over the prefrontal cortex has been applied in participants with spider phobias. It diminished activation in the left inferior frontal gyrus in functional near-infrared spectroscopy (fNIRS) during an emotional Stroop paradigm (59).

\section{Schizophrenia}

Patients with schizophrenia show anhedonia, social withdrawal, and a blunted affect, which can lead to rumination and isolation. While exposure therapy in anxiety-related disorders uses VR as a simulation tool, the so-called avatar therapy for negative symptoms of schizophrenia focuses on interactive VR. In a computer-generated virtual world, VR users are no longer simply external observers, but active participants. It is one of the key variables in understanding social environments that need to be controlled, and thus provides exciting applications to research and treatment (60). For example, interactive VR therapy has shown benefits in social skills such as role-playing (33), memory function (61), medication management skills (62), job interviews (63), and vocational training (64). Recent VR-based cognitive rehabilitation programs also manage positive symptoms in schizophrenia such as auditory verbal hallucinations (11).

\section{Autism}

Autism is characterized by a state of being trapped in one's own world. It is a childhood developmental disability. Children with autism do not interact with others. They do not have emotional ties. VR approaches for rehabilitation in autism tend to create virtual environments integrated with other equipment, facilitating cognitive processes of training such as concentration and other functional skills in everyday life. The University of Texas has developed a training program to assist in the social skills training of autistic children (65). It uses brain imaging and Electroencephalography (EEG) monitoring. It also uses avatars to put children in situations such as job interviews and meetings. They practice reading social signals and expressing socially appropriate behaviors. After completion of the program, the activity of the brain area associated with social understanding was found to be increased in participants' brain image. Smith and colleagues at the Northwestern University Psychiatry Department have reported that young adults diagnosed with autism spectrum have a higher job search rate than the comparative group at six months after receiving job interviews through VR (66). For the purpose of training outdoor activity, individuals with Autism spectrum disorder were placed in a three-dimensional city and given a set of tasks that involved taking buses through a game. A statistically significant increase in measures of knowledge of the process of riding a bus, a reduction in the electro-dermal activity, and a high success rate in their application were found (67).

\section{Dementia and Mild Cognitive Impairment (MCl)}

Lessons from the Nun study have revealed that cognitive reserve and training are also important in preventing Alzheimer's disease (68). Dementia is a broad term describing such disorders of the brain that progress over time. Basically, in evaluating cognitive dysfunction and detecting MCI, VR has been applied and has exhibited very high accuracy. Cushman et al. (69) have investigated navigational impairment of early Alzheimer's disease, using both real-world and laptop PC based virtual environments in the same subjects; 35 young normal controls, 26 older normal controls, 12 patients with mild cognitive impairment and 14 patients with early Alzheimer's disease (AD). It was found that virtual environment testing provides a valid assessment of navigational skills for aging and Alzheimer's disease (69). Also, there is a systematic review that presented a status of VR applications for diagnostic assessment and cognitive training in Alzheimer's disease and MCI. Both semi-immersive and fully-immersive VR technology can be feasible amongst individuals living within the earlier stages of dementia outside of a hospital environment (70). While much of the VR studies appear to focus on the treatment of anxiety or phobias, the population of VR applications is underdeveloped. Even though sample sizes are limited, VR-based cognitive training has shown benefits for episodic memory in Amnestic MCI and early to moderate Alzheimer's disease (71). Moreover, Moyle el al., explored the feasibility of VR in individuals with a range of cognitive impairments from mild to more severe stages of dementia (72). VR was perceived to have a positive effect on people with dementia, although a greater level of fear and anxiety 
during VR were experienced compared to those in the normative sample (72). Some individuals in the earlier stages of dementia experienced boredom, and VR technology was also found to increase fear and anxiety in one study. However, it is perhaps not surprising that recent advances in VR rehabilitation applications keep pointing to the feasibility of VR training in healthy elderly persons as well as in pathological populations (73).

\section{Stress and Pain Alleviation}

Stress and pain have deleterious effects on the mind and body. In order to decrease one's attention available for conscious pain processing, VR usage for stress and pain alleviation typically provides simple forms of distraction (e.g., watching videos or playing video games). Although the physical mechanisms are not well understood, the patients focus moves away from the conscious attention on the stressful and painful condition during the occupational activity (74). While patients can learn painmanagement techniques as mindfulness, several experimental results suggest that VR techniques has actual benefits for subjective pain reduction (75). For example, Oculus Rift uses DEEP, a meditation application to help users breathe deeply. The application works through a band surrounding the chest to measure breathing. In another pilot study, 44 participants attended a mindfulness conference putting on an Oculus Rift DK2 VR helmet and floated down a calm 3D computer-generated virtual river while listening to digitized DBT mindfulness skills training instructions. Participants reported significantly less sadness, anger, and anxiety but more relaxation (76). Dr. Spiegel's team at the Cedars-Sinai Hospital has given chronic patients the opportunity to get out of the hospital through VR and to enjoy the natural scenery. This could reduce a patient's stress and shorten hospital stays (77). Relaxation and meditation in various VR applications have become increasingly widespread for treating patients at home or in hospitals (78).

Studies at the University of Barcelona have shown that applying VR to depressed patients can reduce the severity of their depression and self-degradation and increase satisfaction (79). By limiting distractions from the real world and increasing the sense of presence, VR may facilitate mindfulness practice as well.

\section{Limitations}

Clearly, exposure to VR applications may result in significant discomfort for the majority of people, with symptoms of motion sickness including eye fatigue, headaches, nausea, and sweating $(80,81)$. VR Sickness is different from common motion sickness because motion sickness is caused by visual perception of self-motion while VR sickness does not require actual movement. A conflict between accommodation and vergence depth cues on stereoscopic displays is a significant cause of visual discomfort from VR (82). Dry eyes due to an overheated display in an enclosed space and retinal damage due to blue light are also concerns. As shown in this review, only a few large-sized and well-designed studies have been conducted in psychiatry with VR.

$\mathrm{VR}$ is developing to improve real-life adaptation of patients with psychiatric problems. However, patients may become preoccupied or addicted to the VR environment, similar to internet game addiction. If patients with schizophrenia have impairment on reality testing, they may have delusional thinking in the VR environment. Doctor-patient relationships and careful education before using VR are mandatory before applying VR treatments in psychiatric patients. In the near future, a guideline to apply VR treatments to patients with psychiatric illnesses should be established. VR will play a role as an alternative option for psychiatrists to use in supporting psychiatric assessments and treatments in patients.

\section{CONCLUSION}

Many studies and clinical trials have used VR as a simulation, interaction, and distraction tool for patients with psychiatric illnesses such as PTSD, anxiety, specific phobia, schizophrenia, autism, dementia, and heavy stress. VR environments show the possibility of changing their anxiety, depression, cognition, and social functions by effectively exposing them sources of fear, presenting interactive virtual environments of cognitivebehavioral approaches, and contributing to other rehabilitation applications.

In practice, patients with a psychiatric diagnosis such as depression, bipolar disorder, anxiety disorder, schizophrenia, and even alcohol use disorder share common characteristics such as anxiety, avoidance, and poor insight to their illnesses. Modern VR systems can deliver an ideal place where one can confront the problem which needs to be overcome, not only through talking with doctors, but also through virtual environments with well-controlled sensory stimuli. This may produce cognitive and behavioral changes in patients with psychiatric disorders including autism and dementia. They also have benefits in reducing chronic pain and intensive stress. However, VR needs to overcome technical hurdles such as motion sickness and dry eyes, as well as user hurdles such as preoccupation and addiction.

\section{AUTHOR CONTRIBUTIONS}

All authors listed have made substantial, direct, and intellectual contribution to the work and approved it for publication.

\section{FUNDING}

This work was supported by the Original Technology Research Program for Brain Science through the National Research Foundation of Korea (NRF) funded by the Ministry of Science and ICT (No. NRF-2016M3C7A1947307; PI HJJ), and by the Bio \& Medical Technology Development Program of the NRF funded by the Korean government, MSIT (No. NRF2017M3A9F1027323; PI HJJ). They had no further role in study design; in the collection, analysis and interpretation of data; in the writing of the report; and in the decision to submit the paper for publication. 


\section{REFERENCES}

1. Li L, Yu F, Shi D, Shi J, Tian Z, Yang J, et al. Application of virtual reality technology in clinical medicine. Am J Transl Res (2017) 9:3867-80. doi: 10.4247/AM.2017.ABH187

2. Bekrater-Bodmann R, Foell J, Diers M, Kamping S, Rance M, Kirsch P, et al. The importance of synchrony and temporal order of visual and tactile input for illusory limb ownership experiences - an FMRI study applying virtual reality. PLoS One (2014) 9:e87013. doi: 10.1371/journal.pone.0087013

3. Baus O, Bouchard S. Moving from virtual reality exposure-based therapy to augmented reality exposure-based therapy: a review. Front Hum Neurosci (2014) 8:112. doi: 10.3389/fnhum.2014.00112

4. Mishkind MC, Norr AM, Katz AC, Reger GM. Review of virtual reality treatment in psychiatry: evidence versus current diffusion and use. Curr Psychiatry Rep (2017) 19:80. doi: 10.1007/s11920-017-0836-0

5. Mantovani F, Castelnuovo G, Gaggioli A, Riva G. Virtual reality training for health-care professionals. Cyberpsychol Behav (2003) 6:389-95. doi: $10.1089 / 109493103322278772$

6. Rothbaum BO, Hodges LF, Kooper R, Opdyke D, Williford JS, North M. Effectiveness of computer-generated (virtual reality) graded exposure in the treatment of acrophobia. Am J Psychiatry (1995) 152:626-8. doi: 10.1176/ ajp.152.4.626

7. Doniger GM, Beeri MS, Bahar-Fuchs A, Gottlieb A, Tkachov A, Kenan H, et al. Virtual reality-based cognitive-motor training for middle-aged adults at high Alzheimer's disease risk: a randomized controlled trial. Alzheimers Dement (N Y) (2018) 4:118-29. doi: 10.1016/j.trci.2018.02.005

8. Reger GM, Smolenski D, Edwards-Stewart A, Skopp NA, Rizzo AS, Norr A Does Virtual Reality Increase Simulator Sickness During Exposure Therapy for Post-Traumatic Stress Disorder? Telemed J E Health (2019) in press

9. Flores A, Linehan MM, Todd SR, Hoffman HG. The use of virtual reality to facilitate mindfulness skills training in dialectical behavioral therapy for spinal cord injury: a case study. Front Psychol (2018) 9:531. doi: 10.3389/ fpsyg.2018.00531

10. Peskin M, Wyka K, Cukor J, Olden M, Altemus M, Lee FS, et al. The relationship between posttraumatic and depressive symptoms during virtual reality exposure therapy with a cognitive enhancer. J Anxiety Disord (2019) 61:82-88. doi: 10.1016/j.janxdis.2018.03.001

11. Du Sert OP, Potvin S, Lipp O, Dellazizzo L, Laurelli M, Breton R, et al. Virtual reality therapy for refractory auditory verbal hallucinations in schizophrenia: a pilot clinical trial. Schizophr Res. (2018) 197:176-181. doi: 10.1016/j.schres.2018.02.031

12. Pot-Kolder R, Geraets CNW, Veling W, Van Beilen M, Staring ABP, Gijsman HJ, et al. Virtual-reality-based cognitive behavioural therapy versus waiting list control for paranoid ideation and social avoidance in patients with psychotic disorders: a single-blind randomised controlled trial. Lancet Psychiatry (2018) 5:217-26. doi: 10.1016/S2215-0366(18)30053-1

13. Gold JI, Mahrer NE. Is virtual reality ready for prime time in the medical space? A randomized control trial of pediatric virtual reality for acute procedural pain management. J Pediatr Psychol (2018) 43:266-75. doi: 10.1093/jpepsy/jsx129

14. Gomez J, Hoffman HG, Bistricky SL, Gonzalez M, Rosenberg L, Sampaio $\mathrm{M}$, et al. The use of virtual reality facilitates dialectical behavior therapy $(\mathrm{R})$ "Observing Sounds and Visuals" mindfulness skills training exercises for a latino patient with severe burns: a case study. Front Psychol (2017) 8:1611. doi: 10.3389/fpsyg.2017.01611

15. Ryu JH, Park SJ, Park JW, Kim JW, Yoo HJ, Kim TW, et al. Randomized clinical trial of immersive virtual reality tour of the operating theatre in children before anaesthesia. Br J Surg (2017) 104:1628-33. doi: 10.1002/ bjs. 10684

16. Eijlers R, Legerstee JS, Dierckx B, Staals LM, Berghmans J, Van Der Schroeff MP, et al. Development of a virtual reality exposure tool as psychological preparation for elective pediatric day care surgery: methodological approach for a randomized controlled trial. JMIR Res Protoc (2017) 6:e174. doi: 10.2196/resprot.7617

17. Beidel DC, Frueh BC, Neer SM, Bowers CA, Trachik B, Uhde TW, et al. Trauma management therapy with virtual-reality augmented exposure therapy for combat-related PTSD: a randomized controlled trial. J Anxiety Disord (2019) 61:64-74. doi: 10.1016/j.janxdis.2017.08.005
18. Ferrer-Garcia M, Gutierrez-Maldonado J, Pla-Sanjuanelo J, Vilalta-Abella F, Riva G, Clerici M, et al. A Randomised controlled comparison of secondlevel treatment approaches for treatment-resistant adults with bulimia nervosa and binge eating disorder: assessing the benefits of virtual reality cue exposure therapy. Eur Eat Disord Rev (2017) 25:479-90. doi: 10.1002/ erv. 2538

19. Blume F, Hudak J, Dresler T, Ehlis AC, Kuhnhausen J, Renner TJ, et al. NIRSbased neurofeedback training in a virtual reality classroom for children with attention-deficit/hyperactivity disorder: study protocol for a randomized controlled trial. Trials (2017) 18:41. doi: 10.1186/s13063-016-1769-3

20. Shiban Y, Diemer J, Muller J, Brutting-Schick J, Pauli P, Muhlberger A. Diaphragmatic breathing during virtual reality exposure therapy for aviophobia: functional coping strategy or avoidance behavior? A pilot study. BMC Psychiatry (2017) 17:29. doi: 10.1186/s12888-016-1181-2

21. Bouchard S, Dumoulin S, Robillard G, Guitard T, Klinger E, Forget H, et al. Virtual reality compared with in vivo exposure in the treatment of social anxiety disorder: a three-arm randomised controlled trial. $\mathrm{Br}$ J Psychiatry (2017) 210:276-83. doi: 10.1192/bjp.bp.116.184234

22. Reger GM, Koenen-Woods P, Zetocha K, Smolenski DJ, Holloway KM, Rothbaum BO, et al. Randomized controlled trial of prolonged exposure using imaginal exposure vs. virtual reality exposure in active duty soldiers with deployment-related posttraumatic stress disorder (PTSD). J Consult Clin Psychol (2016) 84:946-59. doi: 10.1037/ccp0000134

23. Norrholm SD, Jovanovic T, Gerardi M, Breazeale KG, Price M, Davis M, et al Baseline psychophysiological and cortisol reactivity as a predictor of PTSD treatment outcome in virtual reality exposure therapy. Behav Res Ther (2016) 82:28-37. doi: 10.1016/j.brat.2016.05.002

24. Son JH, Lee SH, Seok JW, Kee BS, Lee HW, Kim HJ, et al. Virtual reality therapy for the treatment of alcohol dependence: a preliminary investigation with positron emission tomography/computerized tomography. J Stud Alcohol Drugs (2015) 76:620-7. doi: 10.15288/jsad.2015.76.620

25. Jahanishoorab N, Ebrahimzadeh Zagami S, Nahvi A, Mazluom SR, Golmakani $\mathrm{N}$, Talebi $\mathrm{M}$, et al. The effect of virtual reality on pain in primiparity women during episiotomy repair: a randomize clinical trial. Iran J Med Sci (2015) 40:219-24. https://www.ncbi.nlm.nih.gov/pubmed/25999621

26. Rothbaum BO, Price M, Jovanovic T, Norrholm SD, Gerardi M, Dunlop B, et al. A randomized, double-blind evaluation of D-cycloserine or alprazolam combined with virtual reality exposure therapy for posttraumatic stress disorder in Iraq and Afghanistan War veterans. Am J Psychiatry (2014) 171:640-8. doi: 10.1176/appi.ajp.2014.13121625

27. Marco JH, Perpina C, Botella C. Effectiveness of cognitive behavioral therapy supported by virtual reality in the treatment of body image in eating disorders: one year follow-up. Psychiatry Res (2013) 209:619-25. doi: 10.1016/j.psychres.2013.02.023

28. Pallavicini F, Cipresso P, Raspelli S, Grassi A, Serino S, Vigna C, et al. Is virtual reality always an effective stressors for exposure treatments? Some insights from a controlled trial. BMC Psychiatry (2013) 13:52. doi: 10.1186/1471-244X-13-52

29. Diemer J, Domschke K, Muhlberger A, Winter B, Zavorotnyy M, Notzon S, et al. Acute anxiolytic effects of quetiapine during virtual reality exposure-a double-blind placebo-controlled trial in patients with specific phobia. Eur Neuropsychopharmacol (2013) 23:1551-60. doi: 10.1016/j. euroneuro.2013.01.001

30. Malbos E, Rapee RM, Kavakli M. A controlled study of agoraphobia and the independent effect of virtual reality exposure therapy. Aust N Z J Psychiatry (2013) 47:160-8. doi: 10.1177/0004867412453626

31. Mclay RN, Graap K, Spira J, Perlman K, Johnston S, Rothbaum BO, et al. Development and testing of virtual reality exposure therapy for post-traumatic stress disorder in active duty service members who served in Iraq and Afghanistan. Mil Med (2012) 177:635-42. doi: 10.7205/MILMED-D-11-00221

32. Culbertson CS, Shulenberger S, De La Garza R, Newton TF, Brody AL. Virtual reality cue exposure therapy for the treatment of tobacco dependence. J Cyber Ther Rehabil (2012) 5:57-64. https://www.ncbi.nlm.nih. gov/pubmed/25342999

33. Park KM, Ku J, Choi SH, Jang HJ, Park JY, Kim SI, et al. A virtual reality application in role-plays of social skills training for schizophrenia: a randomized, controlled trial. Psychiatry Res (2011) 189:166-72. doi: 10.1016/j.psychres.2011.04.003 
34. Mclay RN, Wood DP, Webb-Murphy JA, Spira JL, Wiederhold MD, Pyne JM, et al. A randomized, controlled trial of virtual reality-graded exposure therapy for post-traumatic stress disorder in active duty service members with combat-related post-traumatic stress disorder. Cyberpsychol Behav Soc Netw (2011) 14:223-9. doi: 10.1089/cyber.2011.0003

35. St-Jacques J, Bouchard S, Belanger C. Is virtual reality effective to motivate and raise interest in phobic children toward therapy? A clinical trial study of in vivo with in virtuo versus in vivo only treatment exposure. J Clin Psychiatry (2010) 71:924-31. doi: 10.4088/JCP.08m04822blu

36. Gerardi M, Rothbaum BO, Ressler K, Heekin M, Rizzo A. Virtual reality exposure therapy using a virtual Iraq: case report. J Trauma Stress (2008) 21:209-13. doi: 10.1002/jts.20331

37. Difede J, Cukor J, Jayasinghe N, Patt I, Jedel S, Spielman L, et al. Virtual reality exposure therapy for the treatment of posttraumatic stress disorder following September 11, 2001. J Clin Psychiatry (2007) 68:1639-47. doi: 10.4088/JCP.v68n1102

38. Walshe DG, Lewis EJ, Kim SI, O'sullivan K, Wiederhold BK. Exploring the use of computer games and virtual reality in exposure therapy for fear of driving following a motor vehicle accident. Cyberpsychol Behav (2003) 6:329-34. doi: 10.1089/109493103322011641

39. Rothbaum BO, Hodges LF, Ready D, Graap K, Alarcon RD. Virtual reality exposure therapy for Vietnam veterans with posttraumatic stress disorder. J Clin Psychiatry (2001) 62:617-22. doi: 10.4088/JCP.v62n0808

40. Rothbaum BO, Hodges L, Smith S, Lee JH, Price L. A controlled study of virtual reality exposure therapy for the fear of flying. J Consult Clin Psychol (2000) 68:1020-6. doi: 10.1037//0022-006X.68.6.1020

41. Rothbaum BO, Hodges L, Alarcon R, Ready D, Shahar F, Graap K, et al. Virtual reality exposure therapy for PTSD Vietnam Veterans: a case study. J Trauma Stress (1999) 12:263-71. doi: 10.1023/A:1024772308758

42. Rothbaum BO, Hodges L, Watson BA, Kessler CD, Opdyke D. Virtual reality exposure therapy in the treatment of fear of flying: a case report. Behav Res Ther (1996) 34:477-81. doi: 10.1016/0005-7967(96)00007-1

43. American Psychiatric Association and American Psychiatric Association. Dsm-5 Task Force. Diagnostic and statistical manual of mental disorders DSM-5. Washington, D.C: American Psychiatric Association (2013). doi: 10.1176/appi.books.9780890425596

44. Rothbaum BO, Rizzo AS, Difede J. Virtual reality exposure therapy for combat-related posttraumatic stress disorder. Ann N Y Acad Sci (2010) 1208:126-32. doi: 10.1111/j.1749-6632.2010.05691.x

45. Norr AM, Smolenski DJ, Reger GM. Effects of prolonged exposure and virtual reality exposure on suicidal ideation in active duty soldiers: an examination of potential mechanisms. J Psychiatr Res (2018) 103:69-74. doi: 10.1016/j.jpsychires.2018.05.009

46. Powers MB, Emmelkamp PM. Virtual reality exposure therapy for anxiety disorders: a meta-analysis. J Anxiety Disord (2008) 22:561-9. doi: 10.1016/j. janxdis.2007.04.006

47. Van 'T Wout M, Spofford CM, Unger WS, Sevin EB, Shea MT. Skin conductance reactivity to standardized virtual reality combat scenes in veterans with PTSD. Appl Psychophysiol Biofeedback (2017) 42:209-21. doi: 10.1007/s10484-017-9366-0

48. Rizzo S. Bravemind: Virtual Reality Exposure Therapy (http://ict.usc.edu/ prototypes/pts/). US: USC (2018).

49. Maples-Keller JL, Bunnell BE, Kim SJ, Rothbaum BO. The use of virtual reality technology in the treatment of anxiety and other psychiatric disorders. Harv Rev Psychiatry (2017) 25:103-13. doi: 10.1097/HRP.0000000000000138

50. Opris D, Pintea S, Garcia-Palacios A, Botella C, Szamoskozi S, David D. Virtual reality exposure therapy in anxiety disorders: a quantitative metaanalysis. Depress Anxiety (2012) 29:85-93. doi: 10.1002/da.20910

51. Carlin AS, Hoffman HG, Weghorst S. Virtual reality and tactile augmentation in the treatment of spider phobia: a case report. Behav Res Ther (1997) 35:153-8. doi: 10.1016/S0005-7967(96)00085-X

52. Garcia-Palacios A, Hoffman H, Carlin A, Furness TA, 3rd, Botella C. Virtual reality in the treatment of spider phobia: a controlled study. Behav Res Ther (2002) 40:983-93. doi: 10.1016/S0005-7967(01)00068-7

53. Klinger E, Legeron P, Roy S, Chemin I, Lauer F, Nugues P. Virtual reality exposure in the treatment of social phobia. Stud Health Technol Inform (2004) 99:91-119. doi: 10.1037/e705482011-034
54. Wallach HS, Bar-Zvi M. Virtual-reality-assisted treatment of flight phobia. Isr J Psychiatry Relat Sci (2007) 44:29-32. https://www.ncbi.nlm.nih.gov/ pubmed/17665808

55. Hong YJ, Kim HE, Jung YH, Kyeong S, Kim JJ. Usefulness of the mobile virtual reality self-training for overcoming a fear of heights. Cyberpsychol Behav Soc Netw (2017) 20:753-61. doi: 10.1089/cyber.2017.0085

56. Raghav K, Van Wijk AJ, Abdullah F, Islam MN, Bernatchez M, De Jongh A. Efficacy of virtual reality exposure therapy for treatment of dental phobia: a randomized control trial. BMC Oral Health (2016) 16:25. doi: 10.1186/ s12903-016-0186-Z

57. Gujjar KR, Van Wijk A, Sharma R, De Jongh A. Virtual reality exposure therapy for the treatment of dental phobia: a controlled feasibility study. Behav Cogn Psychother (2018) 46:367-73. doi: 10.1017/S1352465817000534

58. Chad R, Emaan S, Jillian O. Effect of virtual reality headset for pediatric fear and pain distraction during immunization. Pain Manag. (2018) 8(3):175179. doi: $10.2217 / \mathrm{pmt}-2017-0040$

59. Deppermann S, Notzon S, Kroczek A, Rosenbaum D, Haeussinger FB, Diemer J, et al. Functional co-activation within the prefrontal cortex supports the maintenance of behavioural performance in fear-relevant situations before an iTBS modulated virtual reality challenge in participants with spider phobia. Behav Brain Res (2016) 307:208-17. doi: 10.1016/j. bbr.2016.03.028

60. Freeman D. Studying and treating schizophrenia using virtual reality: a new paradigm. Schizophr Bull (2008) 34:605-10. doi: 10.1093/schbul/sbn020

61. Sohn BK, Hwang JY, Park SM, Choi JS, Lee JY, Lee JY, et al. Developing a virtual reality-based vocational rehabilitation training program for patients with schizophrenia. Cyberpsychol Behav Soc Netw (2016) 19:686-91. doi: 10.1089/cyber.2016.0215

62. Kurtz MM, Baker E, Pearlson GD, Astur RS. A virtual reality apartment as a measure of medication management skills in patients with schizophrenia: a pilot study. Schizophr Bull (2007) 33:1162-70. doi: 10.1093/schbul/sbl039

63. Smith MJ, Fleming MF, Wright MA, Roberts AG, Humm LB, Olsen D, et al. Virtual reality job interview training and 6-month employment outcomes for individuals with schizophrenia seeking employment. Schizophr Res (2015b) 166:86-91. doi: 10.1016/j.schres.2015.05.022

64. Tsang MM, Man DW. A virtual reality-based vocational training system (VRVTS) for people with schizophrenia in vocational rehabilitation. Schizophr Res (2013) 144:51-62. doi: 10.1016/j.schres.2012.12.024

65. Kandalaft MR, Didehbani N, Krawczyk DC, Allen TT, Chapman SB. Virtual reality social cognition training for young adults with highfunctioning autism. J Autism Dev Disord (2013) 43:34-44. doi: 10.1007/ s10803-012-1544-6

66. Smith MJ, Fleming MF, Wright MA, Losh M, Humm LB, Olsen D, et al. Brief report: vocational outcomes for young adults with autism spectrum disorders at six months after virtual reality job interview training. J Autism Dev Disord (2015a) 45:3364-9. doi: 10.1007/s10803-015-2470-1

67. Simoes M, Bernardes M, Barros F, Castelo-Branco M. Virtual travel training for autism spectrum disorder: proof-of-concept interventional study. JMIR Serious Games (2018) 6:e5. doi: 10.2196/games.8428

68. Snowdon DA. Aging and Alzheimer's disease: lessons from the Nun Study. Gerontologist (1997) 37:150-6. doi: 10.1093/geront/37.2.150

69. Cushman LA, Stein K, Duffy CJ. Detecting navigational deficits in cognitive aging and Alzheimer disease using virtual reality. Neurology (2008) 71:88895. doi: 10.1212/01.wnl.0000326262.67613.fe

70. Garcia-Betances RI, Arredondo Waldmeyer MT, Fico G, Cabrera-Umpierrez MF. A succinct overview of virtual reality technology use in Alzheimer's disease. Front Aging Neurosci (2015) 7:80. doi: 10.3389/fnagi.2015.00080

71. Zygouris S, Ntovas K, Giakoumis D, Votis K, Doumpoulakis S, Segkouli S, et al. A preliminary study on the feasibility of using a virtual reality cognitive training application for remote detection of mild cognitive impairment. J Alzheimers Dis (2017) 56:619-27. doi: 10.3233/JAD-160518

72. Moyle W, Jones C, Dwan T, Petrovich T. Effectiveness of a virtual reality forest on people with dementia: a mixed methods pilot study. Gerontologist (2018) 58:478-87. doi: 10.1093/geront/gnw270

73. La Corte V, Sperduti M, Abichou K, Piolino P. Episodic memory assessment and remediation in normal and pathological aging using virtual reality: a mini review. Front Psychol (2019) 10:173. doi: 10.3389/fpsyg.2019.00173 
74. Jones T, Moore T, Choo J. The impact of virtual reality on chronic pain. PLoS One (2016) 11:e0167523. doi: 10.1371/journal.pone.0167523

75. Indovina P, Barone D, Gallo L, Chirico A, De Pietro G, Giordano A. Virtual reality as a distraction intervention to relieve pain and distress during medical procedures: a comprehensive literature review. Clin J Pain (2018) 34:858-77. doi: 10.1097/AJP.0000000000000599

76. Navarro-Haro MV, Lopez-Del-Hoyo Y, Campos D, Linehan MM, Hoffman HG, Garcia-Palacios A, et al. Meditation experts try virtual reality mindfulness: a pilot study evaluation of the feasibility and acceptability of virtual reality to facilitate mindfulness practice in people attending a mindfulness conference. PLoS One (2017) 12:e0187777. doi: 10.1371/journal.pone.0187777

77. Tashjian VC, Mosadeghi S, Howard AR, Lopez M, Dupuy T, Reid M, et al. Virtual reality for management of pain in hospitalized patients: results of a controlled trial. JMIR Ment Health (2017) 4:e9. doi: 10.2196/mental.7387

78. Garrett B, Taverner T, Mcdade P. Virtual reality as an adjunct home therapy in chronic pain management: an exploratory study. JMIR Med Inform (2017) 5:e11. doi: 10.2196/medinform.7271

79. Falconer CJ, Rovira A, King JA, Gilbert P, Antley A, Fearon P, et al. Embodying self-compassion within virtual reality and its effects on patients with depression. BJPsych Open (2016) 2:74-80. doi: 10.1192/bjpo. bp. 115.002147
80. Ohyama S, Nishiike S, Watanabe H, Matsuoka K, Akizuki H, Takeda N, et al. Autonomic responses during motion sickness induced by virtual reality. Auris Nasus Larynx (2007) 34:303-6. doi: 10.1016/j.anl.2007.01.002

81. Chen W, Chao JG, Chen XW, Wang JK, Tan C. Quantitative orientation preference and susceptibility to space motion sickness simulated in a virtual reality environment. Brain Res Bull (2015) 113:17-26. doi: 10.1016/j. brainresbull.2015.01.007

82. Carnegie K, Rhee T. Reducing visual discomfort with HMDs using dynamic depth of field. IEEE Comput Graph Appl (2015) 35:34-41. doi: 10.1109/ MCG.2015.98

Conflict of Interest Statement: The authors declare that the research was conducted in the absence of any commercial or financial relationships that could be construed as a potential conflict of interest.

Copyright (c) 2019 Park, Kim, Lee, Na and Jeon. This is an open-access article distributed under the terms of the Creative Commons Attribution License (CC BY). The use, distribution or reproduction in other forums is permitted, provided the original author(s) and the copyright owner(s) are credited and that the original publication in this journal is cited, in accordance with accepted academic practice. No use, distribution or reproduction is permitted which does not comply with these terms. 